\title{
Impact of Instructional Scaffolding Approach on Secondary School Students Achievement in Mathematics
}

\author{
Nwoke Bright lhechukwu \\ Department of Mathematics, Alvan Ikoku Federal College of Education Owerri, Nigeria \\ *Corresponding author: bincng@yahoo.com | Phone Number: +2348033404186
}

\section{ARTICLE HISTORY}

Received : 22 March 2020

Revised : 18 May 2020

Accepted : 12 September 2020

\section{KEYWORDS}

Instructional Scaffolding;

Achievement;

Mathematics

\begin{abstract}
The study investigated the impact of instructional scaffolding approach on secondary school students' achievement in Mathematics. The study was carried out in Owerri Municipal Council of Imo State. The study was a quasi-experimental research type adopting the pre-test post test non equivalent control design in carrying out the study. A sample of 237 senior secondary school II (SS II) students consisting of 81 males and 156 females was used for the study. The instrument for data collection was a researcher made 30 items objective test questions titled "Mathematics Achievement Test (MAT)". The instrument had reliability coefficient of 0.85 determined using Kuder Richardson 20 formula (KR20). The experiment group was taught mathematics using instructional scaffolding approach while the control group was taught using traditional approach. The data generated was analyzed using mean and standard deviation to answer research questions while Analysis of Covariance (ANCOVA) was used to test the hypotheses at 0.05 level of significance. The result of the study revealed that instructional scaffolding is effective in enhancing secondary school students' achievement in mathematics and minimized gender bias. Based on the result it was recommended that mathematics teachers at secondary school level should apply instructional scaffolding approach in teaching to enhance students'achievement.
\end{abstract}

This is an open access article under the CC-BY-SA license.

\section{INTRODUCTION}

Mathematics has penetrated into all aspects of human endeavour such as education, business, social, politics, domestic activities, etc. It is a leading subject in the study of science and arts. Mathematics cannot be left out in the development of information and communication technology of any nation. The level of mathematics of a nation determines the level of her development both technologically and economically. Andaya (2014) noted that mathematics is considered the mother of all learning in both arts and science. It is essential in almost every field; measurement in fashion, angles in sports, technology and economics. It is seen as a model of thinking, which encourages learners to observe, reflect and reason logically about a problem and in communicating ideas, making it the central intellectual discipline and a vital tool in science, commerce and technology (Iji, 2008, Imoko \& Agwagah, 2006; Nuraina \& Mursalin, 2018). Mathematics is not just computation but a tool for understanding structures, relationship and patterns to produce solutions for complex real life problems (Andaya, 2014). George (2007) stated that mathematics is used either directly or indirectly in providing solution to daily basic human problems such as building, quantity of materials required can be calculated, and other applications by professionals like engineers, doctors, pharmacists among others.

Despite the usefulness of mathematics, students still don't exhibit encouraging performance in the subject area both in internal and external examinations. Maduabum \& Odili (2006) indicated a low achievement in mathematics among students. Many other researchers like Elekwa (2010), Uwadiae (2010), Nufus (2020), Dahliana et al (2019), Nuraina (2018), Mursalin (2019), Usmadi (2020), Niswah (2020), Rind \& Mughal (2020) and Olunloye (2010) variously indicated poor achievement in mathematics by students. This is a clear indication that students mathematics problem solving and learning ability is poor.

The problem may stem from the fact that most mathematics teachers still maintain the use of unproductive teaching method being the traditional method of teaching. The method is teacher-centered as such does not give opportunity for activity based learning which is student-centered. Agommuoh and Ifeanacho (2013) indicated that poor academic achievement in physics and mathematics could be attributed to many factors among which are the teachers' teaching strategies. Most teachers adopt the conventional approach to teaching and the conventional approach is a traditional approach to teaching, whereby the teacher disseminates the information verbally to the students (Kurumeh, Obarakpo, Odoh \& Ikyereve, 2016, Nufus, 2020).

According to Awotala (2011) it is expected that students' learning of mathematics through doing mathematics, using realistic instructional techniques should enhance the inculcation of the generic skills of inquiry, reasoning, conceptualizing, problem-solving and communicating. Learning is a process requiring effort in which the learner actively 
constructs his own meaning that is consistent with prior ideas. The ability of a learner to learn well depends on his/her ability to connect or integrate previous knowledge with new ones and also apply it to real life situations (Nzewi \& Ibeneme, 2011). In other to achieve this state of learning in mathematics, there is need to adopt a more student-centered approach of learning such as the scaffolding instructional approach.

Hammond (2001) defined instructional scaffolding as "support that is designed to provide assistance necessary to enable learners to accomplish and develop understanding that they would not quite be able to manage on their own". It is the support and assistance given in any learning situation when the teacher provides temporary support structures that will assist the learner to develop new understanding, skills, concepts and abilities. Reiser (2004) stated that scaffolding refers to the process by which a teacher, an instructor or a more knowledgeable peer assists a learner, altering the learning task so that the learner can solve problems or accomplish tasks that would ordinarily be impossible for him to learn from the experience. Instructional scaffolding is a learning process designed to promote a deeper level of learning. Scaffolding is the support given during the learning process which is tailored to the needs of the student with the intention of helping the student achieve his/her learning goals (Belland, Glazewski \& Richardson, 2008). Instructional scaffolding in mathematics entails providing necessary support to enhance students learning as new concepts are being presented. Aditi (2017) outlined three essential features of scaffolding to include:

1. It is an effective and collaborative interaction between the teacher and the learner.

2. It works in the area of learners ZPD i.e. zone of proximal development.

3. The support is totally temporary once the goal is achieved it is gradually removed.

This teaching strategy originated from Lev Vygotsky socio-cultural theory and his concert of the Zone of Proximal Development (ZPD) (Raymond, 2000). Lev. Vygotsky described it as the present or real level of development of the learner and the next level attainable by the use of various environmental tools/techniques or capable, knowledgeable, resourceful adults or peers, which acknowledges the actual i.e. initial level of development of the learner and the level which is to be achieved by the use of various strategies used by the educator (teacher) that can be the use of various educational tools, technologies and even by effective adult or peer collaboration (Aditi, 2017; Huda, 2019).

Mathematics as a seemingly abstract subject requires constructivists approaches of learning that is activity oriented and students centered. This will allow the students to get immersed in the learning process thereby developing necessary problem solving skills. Uduafemhe (2015) indicated that students taught using the approaches that are constructivists based demonstrate high academic achievement than those taught using the traditional approach. Since constructivist based approaches are learner-centered they emphasize contextualized and constructive process and equip the students with higher-order thinking skills (Cholewinsk, 2009; Sari et al, 2019). Scaffolding is among the most popularly adopted of constructivists approaches (Uduafemhe, 2015). Simons and Klien (2007) stated that students taught in scaffolding conditions performs significantly better than students taught in non scaffolding condition also, scaffolding enhance inquiry and then performance, especially when students are made to access and make use of them. Alake and Ogunsoemi (2013) stated that students exposed to scaffolding strategy perform significantly well than those who are taught with traditional method.

According to Nzewi and Ibeneme (2011) essential factor in scaffolding is active participation of the learner. This can be encouraged by the teacher as early as the planning state of a new unit of work. Alake and Ogunsoemi (2013) indicated that to carry out scaffolding strategy the teacher must first identify and determine:

1. What students can accomplish independently;

2. What students can accomplish with guidance (in other words, teacher determines the students' zone of proximal development; and

3. Teacher then provides the instructions that are just enough to support the learner in task beyond reach without teacher's support.

Considering the nature and learning process of mathematics it becomes pertinent to try out approaches that will improve students' interest, attitude and ultimately achievement in the subject.

\section{Statement of the Problems}

The persistent poor achievement of students in mathematics has remained a great concern to researchers, parents and stake holders. The situation is attributed to several factors which includes instructional techniques adopted by teachers (Olulonye in Ihendinihu, 2013). The current state of mathematics requires urgent attention to determine effective strategies of enhancing students' achievement and save the nation from plunging into mathematical anarchy which will dim the nations' quest for scientific and technological development.

Therefore, this study was carried out to investigate the impact of instructional scaffolding approach on students' achievement in mathematics.

\section{Purposes of the Study}

The study sought to investigate the impact of instructional scaffolding approach on students' achievement in mathematics. Specifically, the study will determine whether:

1. Students exposed to instructional scaffolding approach will differ in mean achievement scores with those exposed to traditional approach.

2. Gender gap in students' achievement in mathematics will be reduced when exposed to instructional scaffolding approach.

\section{Research Questions}

The following research questions guided the study:

1. What is the difference between the mean achievement scores of students taught mathematics using instructional scaffolding approach and those taught using traditional approach?

2. What is the difference between the mean achievement scores of male and female students taught mathematics using instructional scaffolding approach?

\section{Hypotheses}

The following hypotheses were formulated to guide the study

Ho1: There is no significant difference between the mean achievement scores of students taught mathematics using instructional scaffolding approach and those taught using traditional approach.

Ho2: There is no significant interaction effect between gender and instructional scaffolding approach. 


\section{RESEARCH METHOD}

The study was a quasi-experimental type adopting the pre-test post-test non equivalent control design to investigate the impact of instructional scaffolding approach on students' achievement in mathematics. The design was adopted since it was not possible to perform a randomization of the subjects. The population of the study consist of all the senior secondary school II (SS II) students in the twelve Government owned secondary schools in Owerri Municipal Council of Imo State. Two coeducational secondary schools were purposively selected for the study and in each of the schools selected, two classes were randomly selected and assigned to experiment and control groups. This gave a total sample size of two hundred and thirty seven (237) students comprising of one hundred and fifty six (156) females and eighty one (81) males. The experiment group had 133 students comprising of 43 males and ninety (90) females while the control group comprised of 104 students with 38 males and 66 females. The instrument for data collection was a 30-item objective test questions, titled "Mathematics Achievement Test (MAT)" drawn by the researcher based on the concept that was taught the students as outlined in SS II mathematics syllabus. The construction of the test was guided by a table of specification. The face and content validity of the instrument were determined by two mathematics teachers and a measurement and evaluation expert, their inputs guided the restructuring of the instrument where necessary.

To determine the reliability of the instrument, 30 copies were administered on 30 students outside the study sample and school but with the same characteristics. The data generated were analyzed using Kuder Richardson (KR20) formula which gave a reliability coefficient of 0.85 which was acceptable for the study. To administer the treatment, both experiment and control groups were given a pre-test to determine their readiness. After that, the experiment group was taught solutions of quadratic equation by a research assistant. The research assistant was trained on how to apply scaffolding approach in teaching quadratic equation for two weeks within the interval of three times a week using one hour per contact. The research assistant used a lesson plan drawn based on instructional scaffolding approach to teach the experiment group. During the learning process the teacher provided learning support such as algebra board, number line, multiplication and expansion charts to the students and guided them to apply the supports in discovering answers to problem situations. For instance, to solve a quadratic equation, the teacher provided idea through factorization and expansion using the algebra board and guided the students to discover the roots of the quadratic equation. In this situation, when the students master any step of solving the quadratic problem, the support was withdrawn to allow them move to another step. The students were allowed to cooperate with each order, share ideas and interact with the teacher without limit. The researcher monitored the entire process to ensure that the steps outlined on the lesson plan were strictly maintained. The control groups were taught the same concept with a lesson plan that was drawn based on the traditional approach by their regular mathematics teacher. The entire process lasted for 3 weeks after which a post-test was administered to both groups using a rearranged version of the pre-test instrument and marked over $100 \%$. The generated data was analyzed using mean and standard deviation to answer research questions while the hypotheses were tested using Analysis of Covariance (ANCOVA) at 0.05 level of significance.

\section{RESULTS AND DISCUSSION}

\section{Results}

Research Question 1:

What is the difference between the mean achievement scores of students taught mathematics using instructional scaffolding approach and those taught using traditional approach ?.

\begin{tabular}{|c|c|c|c|c|c|c|}
\hline Group & $\mathbf{N}$ & Test & Mean & SD & $\begin{array}{c}\text { Mean } \\
\text { gain }\end{array}$ & $\begin{array}{c}\text { Diff in } \\
\text { Ach }\end{array}$ \\
\hline \multirow[t]{2}{*}{ Expt. } & 133 & Pre-test & 30.16 & 8.48 & 21.61 & \\
\hline & & Post-test & 51.77 & 9.17 & & 18.87 \\
\hline \multirow[t]{2}{*}{ Contr. } & 104 & Pre-test & 30.02 & 8.35 & 2.74 & \\
\hline & & Post-test & 32.76 & 8.96 & & \\
\hline
\end{tabular}

Table 1 shows that the experiment group had a mean of 30.16 and SD of 8.48 in the pre-test with 51.77 and 9.17 in the post test, this gave a mean gain of 21.61 while the control group had mean of 30.02 and SD of 8.35 in the pre-test with 32.76 and 8.96 in the post-test, this gave a mean gain of 2.74. These gave a difference in mean achievement score of 18.87 in favour of the experiment group.

\section{Research Question 2:}

What is the difference between the mean achievement scores of male and female students taught mathematics using instructional scaffolding approach ?.

Table 2. Summary of Gender Achievement in Experiment

\begin{tabular}{ccccccc}
\hline Group & $\mathrm{N}$ & Test & Mean & SD & $\begin{array}{c}\text { Mean } \\
\text { gain }\end{array}$ & $\begin{array}{c}\text { Diff in } \\
\text { Ach }\end{array}$ \\
\hline Male & 43 & Pre-test & 31.94 & 8.51 & 17.71 & \\
\hline & & Post-test & 49.65 & 8.72 & & 1.85 \\
\hline Female & 90 & Pre-test & 33.23 & 8.7 & 19.56 & \\
\hline & & Post-test & 52.79 & 9.25 & & \\
\hline
\end{tabular}

Table 2 shows that the male students had mean of 31.94 and SD of 8.51 in the pre-test with mean of 49.65 and SD of 8.72 in the post-test with mean gain of 17.71 while female students had mean of 33.23 and SD of 8.57 in the pre-test with mean of 52.79 and SD of 9.25 in the post-test with mean gain of 19.56. These gave difference in achievement score of 1.85 in favour of the female students.

$\mathrm{Ho}_{1}$ : There is no significant difference between the mean achievement scores of students taught mathematics using instructional scaffolding approach and those taught using traditional approach.

$\mathrm{Ho}_{2}$ : There is no significant interaction effect between gender and instructional scaffolding approach.

Table 3. Summary of ANCOVA Analysis on Students' Achievement

\begin{tabular}{llllll}
\hline \multicolumn{1}{c}{ Source } & $\begin{array}{c}\text { Type III sum } \\
\text { of squares }\end{array}$ & df & Mean square & $\mathbf{f}$ & Sig. \\
\hline Corrected model & 21461.160 & 4 & 5365.290 & 65.465 & .000 \\
\hline Intercept & 27435.977 & 1 & 27435.977 & 334.744 & .000 \\
\hline Covariate & 33.300 & 1 & 33.300 & .406 & .524 \\
\hline Gender & 228.999 & 1 & 228.999 & 2.784 & .096 \\
\hline Method & $\mathbf{1 8 2 6 2 . 8 3 0}$ & $\mathbf{1}$ & $\mathbf{1 8 2 6 2 . 8 3 0}$ & $\mathbf{2 2 2 . 8 2 4}$ & $\mathbf{. 0 0 0}$ \\
\hline Gender*Method & $\mathbf{3 0 . 9 0 2}$ & $\mathbf{1}$ & $\mathbf{3 0 . 9 0 2}$ & $\mathbf{. 3 7 7}$ & $\mathbf{. 5 4 0}$ \\
\hline Error & 19014.942 & 232 & 81.961 & & \\
\hline Total & 487505.00 & 232 & & & \\
\hline Correct Total & 40476.101 & 236 & & & \\
\hline
\end{tabular}


Table 3 shows that the f-calculated value 222.824 for method is greater than the critical value 3.84 also, $\mathrm{P}<0.05$. Based on the result, the null hypothesis is rejected and alternative accepted. This implies that there is a significant difference between the mean achievement scores of students exposed to instructional scaffolding approach and those exposed to traditional approach.

Table 3 also shows that the f-calculated value 0.377 for gender and method is less than the table value 3.84 and $\mathrm{P}>0.05$. Based on the result, the null hypothesis is upheld at 0.05 level of significance.

\section{Discussions}

The result of the study revealed that students taught mathematics using instructional scaffolding approach had better achievement than their counterparts taught using the traditional approach. Further statistical analysis indicated a significant difference between the mean achievement scores of students exposed to instructional scaffolding approach and those exposed to traditional approach. This is suspected to have resulted from the nature of the approach as it allowed for students centeredness, activity based learning and cooperative learning. This results is in agreement with that of Alake and Ogunseemi (2013) which revealed that students taught with scaffolding strategy performed better than their counterparts taught with chalk and talk method. Nzewi and Ibeneme (2011) which showed that students taught elected biology topics using scaffolding approach performed better than those taught using the conventional method (lecture method) and Mathsolutions (2016) which stated that scaffolding learning helps students achieve greater gains in mathematics class than they would otherwise.

The result of the study revealed that gender is not a factor in students' achievement in mathematics when instructional scaffolding approach is applied in teaching. A further analysis of the results showed no significant interaction effect between gender and Instructional scaffolding approach. This result is in agreement with Ogundola, Abiodun and Jonathan (2010) who reported that there was no significant difference in the mean scores of male and female students taught with constructivism instructional approach such as scaffolding and collaborative approaches.

\section{CONCLUSION}

The result of the study revealed that instructional scaffolding is very effective in teaching and learning mathematics as it enhanced students' achievement and minimize gender bias.

\section{Recommendations}

Based on the results of the study, the following recommendations are made :

1. Mathematics teachers at the secondary school level should apply instructional scaffolding approach in teaching as to enhance students' achievement.

2. Curriculum planners should adopt instructional scaffolding as an adequate teaching method to teaching mathematics.

3. Workshops, seminars, and symposium should be organized for teachers to enlighten them on the importance and use of scaffolding approach in teaching mathematics.

\section{REFERENCES}

Aditi, B. (2017). Effect of instructional scaffolding on high school students' academic achievement and attitude towards science. International Journal of Science Technology and Management, 6(3), 228 - 235

Agommuoh, P. O. \& Ifeanyi, A. O. (2013). Secondary school students assessment of innovative teaching strategies in enhancing achievement in physics and mathematics. IOSR Journal or Research \& Method in Education (IOSR-IRME), 3(5), $06-11$

Alake, E. M. \& Ogunseemi, O. E. (2013). Effects of scaffolding strategy on learners' academic achievement in integrated science at the junior secondary school level. European Scientific Journal, 9(11), 149 - 155

Andaya, O. J. F. (2014). Factors that affect mathematics achievement of Students of Philippine Normal University. Isabela Campus International Refereed Research Journal, (1) 4,83-91

Awofala, A. O. A. (2011). Effect of concept mapping strategy on students' achievement in junior secondary school mathematics. International Journal of Mathematics Trends and Technology, 2(3), $11-16$

Belland, Gkazewsjum J, D, \& Richardson, J. C. (2008). A scaffolding framework to support the construction of existence-based arguments among middle school students. Education Tech. Research Dev. 56, 401 - 422

Cholewinski, M. (2009). An introduction to constructivism and authentic activity. Retrieved from www.library.nakanishi.ac.ip on 8/5/2017

Dahliana, D., Marhami, M., \& Mursalin, M. (2019). Improving Students' Mathematical Critical Thinking Abilities Through the Problem Solving Method on the Sequences and Series Course. International Journal for Educational and Vocational Studies, 1(7), 813-816. DOI: https://doi.org/10.29103/ijevs.v1i7.2571

Elekwa, U. C. C. (2010). Effects of collaborative teaching/learning strategies on the mathematics achievement of senior secondary school students in Abia State of Nigeria. Unpublished Ph.D Thesis, Faculty of Education, University of Port Harcourt

George, H. H. (2007). Assessment and grading in high school mathematic classroom. Journal of Mathematics Association Nigeria. 33(2), $412-418$

Hammond, J. (2001). Scaffolding: teaching and learning in language and literacy education. Rozelle PETA.

Huda, S., \& Agustyaningrum, N. (2019). An Analysis of Sensory Integration Approach on Counting Skills Among Children With Special-Needs. Malikussaleh Journal of Mathematics Learning (MJML), 2(2), 52-55.

Ihendinihu, U.E. (2013). Enhancing mathematics achievement of secondary school students using mastery learning approach. Journal of emerging Trends in educational Research and Policy Studies(JETERAPS), $4(6), 848-854$.

Iji, C. O. (2000). Reforming school mathematics curriculum in line with global challenges. Proceedings of the $49^{\text {th }}$ Annual conference of STAN. Pp. $226-230$

Imoke, I. B. \& Agwagah, U. N. (2006). Improving students' interest in mathematics through the concept mapping technique. A focus on gender. Journal of Research in Curriculum and Teaching, 1(1), 30- 31

Kurumeh, M. S., Obarakpo, J. S., Odoh, C. O. \& Ikyereye, R. O. (2016). 
Enhancing senior secondary school students' achievement in geometry through the utilization of Rusbult problem solving model in Keffi Metropolis, Nasarawa State, Nigeria. Merit Research Journals 4(6),65-70

Maduabum, M. A. \& Odili, g. a. (2006). Analysis of students' performance in mathematics from $1991-2002$. Journal of Research in Curriculum and Teaching, 1(1), $64-68$

Math Solutions (2016). What is scaffold learning? Retrieved from https://mathsolutions.com/ uncategorized/what-is-scaffol d-learning/ on $25^{\text {th }}$ sept 2017

Mursalin, M. (2019). The Critical Thinking Abilities in Learning Using Elementary Algebra E-Books: A Case Study at Public Universities in Indonesia. Malikussaleh Journal of Mathematics Learning (MJML), 2(1), 29-33.

Niswah, U., \& Qohar, A. (2020). Mathematical Reasoning in Mathematics Learning on Pyramid Volume Concepts. Malikussaleh Journal of Mathematics Learning (MJML), 3(1), 23-26.

Nufus, H., \& Mursalin, M. (2020). Improving Students' Problem Solving Ability and Mathematical Communication through the Application of Problem Based Learning. Electronic Journal of Education, Social Economics and Technology, 1(1), 43-48. DOI: 10.33122/ejeset.v1i1.8

Nuraina, N., \& Mursalin, M. (2018). Improving Students' Mathematical Communication Skills Through Learning Start Learning Models With A Question on Pythagoras. Malikussaleh Journal of Mathematics Learning (MJML), 1(2), 44-47. DOI: https://doi.org/10.29103/mjml.v1i2.2231

Nzewi, U. \& Ibeneme, A. N. (2011) The effect of cueing questions as instructional scaffolding on students' achievement biology. Retrieved from

http://stanonline.org/journal/JSTAN-on 2nd oct. 2017.

Ogwudola, J. P., Abiodun, A. P. \& Jonathan, O. O. (2010). Effects ofconstructivist instructional approach on teaching practical skills to mechanical related trade students in Western Nigeria technical colleges. International NGO Journal. 5(3), $59-64$

Olunloye, O. (2010). Mass failure in mathematics: A national disaster.Tribune of $07 / 02 / 2010$. Retrieved from http://www.tribune.com.ng on 20/8/2017

Raymond, E. (2000). Cognitive characteristics learners with mild disabilities. Allyn \& Bacon, Needhasn Heights

Reiser, B. J. (2004). Scaffolding complex learning: The mechanisms of structuring and problematizing student work. The Journal of the Learning Science, 13(3), 273 - 304

Rind, A. A., \& Mughal, S. H. (2020). An Analysis of Pakistan's National Curriculum of Mathematics at Secondary level. Electronic Journal of Education, Social Economics and Technology, 1(1), 39-42.

Sari, I., Marwan, M., \& Hajidin, H. (2019). Students' Thinking Process in Solving Mathematical Problems in Build Flat Side Spaces of Material Reviewed from Adversity Quotient. Malikussaleh Journal of Mathematics Learning (MJML), 2(2), 61-67.

Simons, K. D. \&\& Klein, J. D. (2007). The impact of scaffolding and students' achievement levels in a problem-based learning environment instructional science. 35(1), $41-72$

Uduafemhe, M. E. (2015). Comparative effects of scaffolding and collaborative instructional approaches on secondary school students' psychomotor achievement in basic electronics in North-central Nigeria. 10SR Journal of Engineering (10SRJEN) 5(6), 23 - 31
Uwadaiae, I. (2010). WAEC releases May/June WASSCE results. Thisday Newspaper of 20/8/2017.

Usmadi, U., Hasanah, H., \& Ergusni, E. (2020). The impact of the implementation three-step interview cooperative learning model in mathematics learning toward the learners' activities and outcomes. Malikussaleh Journal of Mathematics Learning (MJML), 3(1), 8-12. 